\title{
The correlation of visual inspection, Pap-smear and immunocytochemistry of human papilloma virus in detection of cervical cytology
}

\author{
Anuradha Khemka*, Shubhada Jajoo
}

Department of Obstetrics and Gynecology, Datta Meghe Institute of Medical Sciences, Wardha, Maharashtra, India

Received: 23 October 2016

Accepted: 23 November 2016

\section{*Correspondence:}

Dr. Anuradha Khemka,

E-mail: anuradha.khemka@yahoo.in

Copyright: () the author(s), publisher and licensee Medip Academy. This is an open-access article distributed under the terms of the Creative Commons Attribution Non-Commercial License, which permits unrestricted non-commercial use, distribution, and reproduction in any medium, provided the original work is properly cited.

\begin{abstract}
Background: Carcinogenicity presents as a major challenge to scientists and society.. Cervical cancer ranks fifth in the world and is the second cause of death in developing countries like India and China. The rate of death due to cervical cancer is greatest in India. At any time women are at risk of harboring HPV infection, which has been seen to cause cervical cancer. Clinical judgment should be used in spite of all high quality modalities available for screening and diagnosis, as initiated by WHO (World health organization) the Down Staging of cervical cancer, VIA, VILI, Pap smear introduced by George Papanicolaou in 1940s, HPV testing by Immunocytochemistry (ICC) and HPV DNA, Colposcopy, are other modalities to screen cervix. The study aims to evaluate the correlation between Pap smear, visual inspection and Immunocytochemistry of Human papilloma virus (HPV).

Methods: All 100 consecutive women were subjected to visual inspection of cervix, Pap smear and immunocytochemistry of HPV. Pap smear was done by conventional method.

Results: it was seen that out 100 consecutive cervico-vaginal, ears for Pap and Immunocytochemistry, only 33 were abnormal, 24 were ASCUS, 6 were LSIL, 2 were HSIL, 1 was SCC and 67 were NILM out of which 3 were reactive for ICC. And all 33 were reactive for ICC.

Conclusions: The p16 immunostaining performed on conventional smears can become alternative or addition to 1 HPV DNA tests. The Bethesda System (TBS) 2001 for reporting cervical cytology diagnosis is of high value in detecting abnormal cervical cytology. It is further concluded that the ancillary screening for HPV in NILM category seems to be not advisable as percentage of detection of HPV in this category is low.
\end{abstract}

Keywords: ASCUS, DNA, HPV, HSIL, ICC, LSIL, SCC, NILM, p16INK4a, TBS

\section{INTRODUCTION}

Carcinogenicity presents as a major challenge to scientists and society. Our health services are adequately equipped with facilities and expertise for diagnosis and management of cancers. The technology is available in the country; the need is to network the centers in public and private sectors with strict quality control. . There should be adequate screening programs to detect precancerous conditions. Mortality and morbidity due to cancers are very high but remains undetected. The focus should be to identify the preventable risk factors and understand the mechanism of carcinogenesis. There should be adequate screening programs to detect precancerous condition and preventable causes involving clinical, epidemiological and modern molecular techniques.

Cervical cancer ranks fifth in the world and is the second cause of death in developing countries like India and China. There are almost 365.71 million women who are above age of 15 years and are at risk of developing malignancy. Worldwide India alone accounts for about $1 / 3^{\text {rd }}$ load of death from cervical cancer with current estimates of 1,32,000 new cases per year and 74,000 deaths annually. ${ }^{1}$ At any time women are at risk of 
harboring HPV infection, which has been seen to cause cervical cancer. The primary prevention from Human papilloma virus (HPV) can be attained by complete abstinence of sexual activity and mass immunization against high risk from Human papilloma virus (HPV). For a developing country like India to screen large population we need measures, which are economical, acceptable, and feasible to both clinicians and women. Clinical judgment should be used in spite of all high quality modalities available for screening and diagnosis, as initiated by WHO (World health organization) the Down Staging of cervical cancer. The cervical cytology by Pap-smear and HPV testing are important advents in the screening of cervical cancer. Therefore such a study would provide us with valuable information about diagnosis of HPV infection along with cervical cytology and visual inspection as a better factor in evaluation of precancerous conditions of cervix leading to invasive carcinoma. The HPV is recognized as major cause of cervical cancer.

Infection of the cervical epithelium with oncogenic types of Human Papilloma virus (HPV) is essential for the development of precursor lesion and cervical cancer. ${ }^{2}$ The main problem is to identify from the large number of HPV positive patients the ones who are at risk of progressive disease. HPV genotyping can establish the presence of high risk HPV, subclinical and clinical relevant infections. Neither cytological tests nor HPV DNA typing can indicate whether there will be remission or progression to invasive disease. Therefore it is necessary to identify some markers to offer information, concerning the HPV status and progressive risk. So it becomes prudent to know the immunocytochemical expression of biomarker p16INK4a and HPV L1 capsid protein in detection of HPV infection. HPV L1 capsid protein is expressed in the early productive phase of cervical carcinogenesis and is lost in later phases when p16 INK4a gets overexpressed. ${ }^{3}$ Hence for women's preventive health care, screening plays a central role. Now we enter the CO-testing era of clinical evaluation, Cytology and Human Papilloma Virus testing (Immunocytochemistry) at the same setting.

The study aims to evaluate the correlation between Pap smear, visual inspection and Immunocytochemistry of Human papilloma virus (HPV).

\section{Objectives}

- To establish correlation between results of Pap smear, Visula inspection and immunocytochemistry.

- To study the correlation of socio-demography with Pap smear and immunocytochemistry of Human Papilloma Virus (HPV).

\section{METHODS}

The study was conducted on 100 consecutive patients visiting Acharya Vinoba Bhave Rural Hospital (AVBRH)
Gynecology outpatient department (OPD). Visual inspection, Pap smear and immunocytochemistry for HPV were done at the same sitting. The design chosen for this study was prospective type. All women who gave consent for study were selected. Married women, age above 25 years was the inclusion criteria. Women below 24 years, post hysterectomy and already diagnosed cases of cancer with radiotherapy were not included. Cervix was examined by naked eyes, per speculum and per vaginum examination was performed and readings were noted in pre-designed proforma. Cervical cytology was collected by conventional technique and slide was prepared for Papanicolaou smear. Simultaneously Ayres disposable spatula was used for collection of cells from the transformation zone. The end of spatula was used to shed cervical cells to a solution of $2 \mathrm{ml}$ normal saline in a pre-labelled glass vial, and immediately taken to cytopathology for cytospin preparation for immunocytochemistry (ICC) of HPV. Papanicolaou smear was reports as per The Bethesda system and ICC slides were stained. Monoclonal mouse antibody (LOT NO- 10064645, DAKO, Code M3528) was used for immunocytochemistry that is Immunoreactive with HPV infected issue. The immunostaining was performed as detailed by manufacturer's instructions.

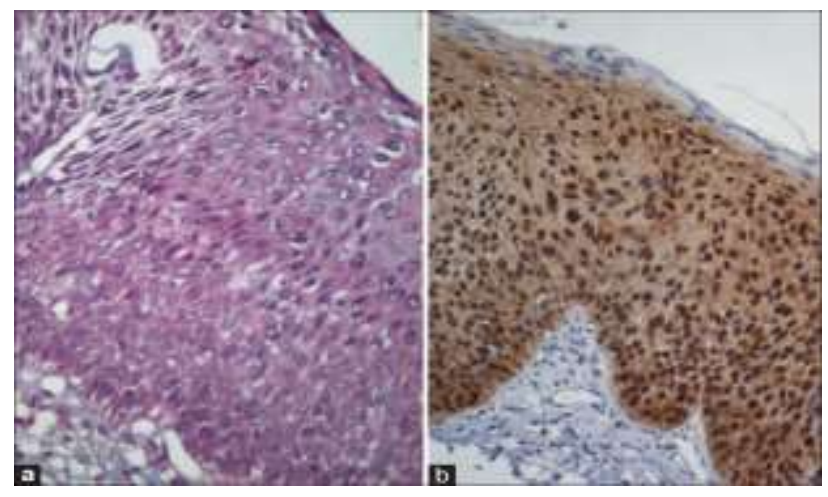

Figure 1: (a) Abnormal cervical cells stained by Papanicolaou method; (b) Cervical cells when immunostained for p16INK4a by cytospin for Human Papilloma Virus. When seen under light microscope staining of nucleus and cytoplasm brown was suggestive of infection with HPV.

\section{Statistical analysis}

Data are reported as number (percentage) and mean (Standard deviation). Association of outcome and exposure was tested with t-test and exposure to more than two categories with the non-parametric trend Pearson chisquare test. $\mathrm{P}<0.05$ was considered significant.

\section{RESULTS}

Table 1 shows the distribution of socio-demographic data (mean age, residence, occupation and mean income) of 100 women who participated in the study. 
Table 1 shows the 100 women enrolled for the study, The Mean age was 41.96 years with standard deviation of 10.98 , majority of the women were from rural area being $57 \%$, nearly half of the study population was from villages and rest were from urban area $43 \%$. Forty-three women were home-makers $(43 \%), 50$ were farm labourers $(50 \%)$ and 7 were clerk $(7 \%)$. The mean income in rupees of the study population was seven thousand three hundred forty rupees with SD of 4524.91 .

Table 1: Distribution of socio-demographic data.

\begin{tabular}{|c|c|c|}
\hline $\begin{array}{l}\text { Mean age in years (standard } \\
\text { deviation SD) }\end{array}$ & 41.96 & (10.98) \\
\hline \multicolumn{3}{|l|}{ Type of residence (\%) N=100 } \\
\hline Urban & 43 & $(43 \%)$ \\
\hline Rural & 57 & $(57 \%)$ \\
\hline \multicolumn{3}{|l|}{ Occupation $(\mathrm{N}=100)$} \\
\hline Homemaker & 43 & $(43 \%)$ \\
\hline Farm labor & 50 & $(50 \%)$ \\
\hline Clerk & 7 & $(7 \%)$ \\
\hline $\begin{array}{l}\text { Mean income in rupees (standard } \\
\text { deviation SD) }\end{array}$ & 7430 & $(4524.91)$ \\
\hline
\end{tabular}

Table 2: The data of 100 women who underwent clinical evaluation of cervix by visual inspection, Pap smear and immunocytochemistry.

\begin{tabular}{|lll|}
\hline Visual inspection $(\mathrm{N}=100)$ & No. & $(\%)$ \\
\hline Normal & 54 & \\
\hline Abnormal & 46 & $(46 \%)$ \\
\hline $\begin{array}{l}\text { Cervical cytology by Papanicolaou } \\
\text { smear (N=100) }\end{array}$ & No. & $(\%)$ \\
\hline NILM & 67 & \\
\hline ASCUS & 24 & $(24 \%)$ \\
\hline LSIL & 6 & $(6 \%)$ \\
\hline HSIL & 2 & $(2 \%)$ \\
\hline SCC & 1 & $(1 \%)$ \\
\hline $\begin{array}{l}\text { Immunocytochemistry (ICC) for } \\
\text { Human Papilloma virus (N=100) }\end{array}$ & No. & $(\%)$ \\
\hline Positive & 36 & $(36 \%)$ \\
\hline Negative & 64 & $(64 \%)$ \\
\hline
\end{tabular}

Table 2 shows the data of 100 study participants subjected for clinical evaluation of cervix, cervical cytology by conventional method (Pap smear), and immunocytochemistry of Human Papilloma virus (HPV). On visual inspection there were $46 \%$ with unhealthy cervix, rest $54 \%$ were healthy. There were $67 \%$ patients who were negative for intraepithelial malignancy (NILM), $24 \%$ (24) patients had atypical cells of undetermined significance (ASCUS), 6\% (6) had lowgrade squamous intraepithelial lesion (LSIL), $2 \%$ (2) had high-grade squamous intraepithelial lesion (HSIL) and only $1 \%$ (1) women had squamous cell carcinoma.

$36 \%$ patients reacted positive for immunostaining (ICC) for HPV and $64 \%$ were negative.
Table 3: The percentage of abnormal cervical cytology.

\begin{tabular}{|llll|}
\hline $\begin{array}{l}\text { Abnormal } \\
\text { (N=33) }\end{array}$ cervical cytology & No. & $(\%)$ \\
\hline $\begin{array}{l}\text { Atypical squamous } \\
\text { undetermined } \\
\text { (ASCUS) }\end{array}$ & $\begin{array}{c}\text { cells of } \\
\text { significance }\end{array}$ & 24 \\
\hline $\begin{array}{l}\text { Low grade } \\
\text { intraepithelial lesions(LSIL) }\end{array}$ & squamous & 6 & $(46 \%)$ \\
\hline $\begin{array}{l}\text { High grade } \\
\text { intraepithelial lesions }\end{array}$ & squamous & 2 & $(\%)$ \\
\hline \begin{tabular}{l} 
Squamous cell carcinoma (SCC) \\
\hline
\end{tabular} & & 1 \\
\hline
\end{tabular}

Out of 100 cervical cytology done 33 were abnormal, out of which $72.7 \%$ was ASCUS, $18.18 \%$ were LSIL, $6.06 \%$ were HSIL and $3.03 \%$ were SCC. Maximum no. of cases was of atypical squamous cells of undetermined significance.

Table 4: The correlation between the sociodemographic data and immunocytochemistry for HPV.

\begin{tabular}{|c|c|c|c|c|}
\hline Parameters & $\begin{array}{l}\text { ICC } \\
(+v e) \\
N=36\end{array}$ & $\begin{array}{l}\text { ICC } \\
N=64 \\
(-\mathrm{Ve})\end{array}$ & P value & $\begin{array}{l}\text { Analysis } \\
\text { by- }\end{array}$ \\
\hline $\begin{array}{l}\text { Mean age } \\
\text { in years } \\
\text { (SD) }\end{array}$ & $\begin{array}{l}44.59 \\
(12.14)\end{array}$ & $\begin{array}{l}40.42 \\
(10.05)\end{array}$ & 0.0616 & (t-test) \\
\hline \multicolumn{5}{|l|}{ Residence } \\
\hline $\begin{array}{l}\text { Urban } \\
(\mathrm{N}=43)\end{array}$ & 8 & 35 & \multirow[t]{2}{*}{$\begin{array}{l}0.002 \\
\text { (s) }\end{array}$} & \multirow{2}{*}{$\begin{array}{l}\text { (chi- } \\
\text { square } \\
\text { test) }\end{array}$} \\
\hline $\begin{array}{l}\text { Rural } \\
(\mathrm{N}=57)\end{array}$ & 28 & 29 & & \\
\hline \multicolumn{5}{|l|}{ Occupation } \\
\hline $\begin{array}{l}\text { Home } \\
\text { maker (43) }\end{array}$ & 12 & 31 & \multirow[t]{3}{*}{$0.016(\mathrm{~s})$} & \multirow{3}{*}{$\begin{array}{l}\text { (chi- } \\
\text { square } \\
\text { test) }\end{array}$} \\
\hline $\begin{array}{l}\text { Farm labor } \\
(50)\end{array}$ & 24 & 26 & & \\
\hline Clerk (7) & 0 & 7 & & \\
\hline $\begin{array}{l}\text { Mean } \\
\text { income in } \\
\text { rupees (SD) }\end{array}$ & $\begin{array}{l}5944 \\
(4222.01)\end{array}$ & $\begin{array}{l}8265.62 \\
(4505.7)\end{array}$ & $\begin{array}{l}0.0131 \\
\text { (s) }\end{array}$ & $\begin{array}{l}\text { (chi- } \\
\text { square } \\
\text { test) }\end{array}$ \\
\hline
\end{tabular}

Considering immunocytochemistry as gold standard for diagnosing HPV we compared the demographic data of our study population with the results of immunostaining. It was seen the mean age of women positive for HPV infection was 44.59 years and 40.42 years was mean age of women who were negative for immunostaining with SD (10.05) with $\mathrm{p}$ value of 0.0616 by t-test, which was not significant. Out of 57 women who stayed in rural area 28 were positive for HPV and rest 29 were negative and out of 43 women who stayed in urban area only 8 were reactive to immunostaining rest 35 were negative with significant $p$ value 0.002 with chi-square test. Out of 50 farm labourers 24 tested positive for ICC rest 26 were negative, out of 43 homemakers 12 were positive rest 31 were negative none of the clerks were positive for ICC 
with a significant $\mathrm{p}$ value of 0.002.that is immunostaining was seen in majority of farm labourers. The mean income of the women who were positive was rupees 5944, and women who were negative for HPV had mean income of rupees 8265.62 with significant $\mathrm{p}$ value 0.0131 by t-test i.e. HPV infection was more in low socio- economic class women.

Table 5: The correlation between visual inspection of cervix, cervical cytology by Pap smear and immunocytochemistry.

\begin{tabular}{|c|c|c|c|c|}
\hline & $\begin{array}{l}\text { ICC } \\
\text { (+ve) } \\
\mathbf{N}=36\end{array}$ & $\begin{array}{l}\text { ICC } \\
\text { (-ve) } \\
\mathbf{N}=64\end{array}$ & P value & Analysis \\
\hline \multicolumn{5}{|c|}{ Cervical cytology by pap smear $(\mathrm{N}=100)$} \\
\hline $\begin{array}{l}\text { Abnormal } \\
(\mathrm{N}=33)\end{array}$ & 33 & 0 & \multirow[t]{2}{*}{$<0.05(\mathrm{~s})$} & \multirow[t]{2}{*}{ Chi- $^{2 \text { test }}$} \\
\hline $\begin{array}{l}\text { Normal } \\
(\mathrm{N}=67)\end{array}$ & 3 & 64 & & \\
\hline \multicolumn{5}{|c|}{ Visual inspection $(\mathrm{N}=100)$} \\
\hline $\begin{array}{l}\text { Abnormal } \\
(\mathrm{N}=46)\end{array}$ & 29 & 17 & \multirow[t]{2}{*}{$<0.05(\mathrm{~s})$} & \multirow[t]{2}{*}{$\mathrm{Chi}^{2}{ }^{2 \text { test }}$} \\
\hline $\begin{array}{l}\text { Normal } \\
(54)\end{array}$ & 7 & 47 & & \\
\hline
\end{tabular}

Table 4 shows the correlation between all three interventions done in present study visual inspection of cervix, cervical cytology and immunocytochemistry for HPV. Out of 100 women only 33 had abnormal Pap smear but all 33 were positive for ICC, there were 67 women with normal cervical cytology out of which 64 were negative for ICC with highly significant $\mathrm{p}$ value of $<0.05$., by chi-square test and only 3 out of 67 NILM were reactive for ICC $(4.47 \%)$. There were 46 women with abnormal (unhealthy) looking cervix out of which 29 were positive for HPV ,54 had normal looking cervix and 47 of them were negative for ICC with significant $p$ value of $<0.05$,by chi-square test. The clinical evaluation of cervix is a very important step in diagnosing pathology at an early stage. To screen NILM category with HPV did prove to be beneficial.

\section{DISCUSSION}

In our study we included 100 consecutive women attending AVBRH outdoor patient department. The over expression of p16-INK4a by immunocytochemistry was compared with cervical cytology by Papanicolaou test (conventional method) and visual inspection of cervix.

Many studies on p16 cytology have been published, most of them have used convenience samples or consecutive specimens of a particular cytological diagnosis either taking specifically abnormal cervical smears or retrospectively investigating HPV in higher grades of cervical dysplasia. Table below summarizes 9 large studies incorporating almost 1,510 specimens (Kate $\mathrm{C}$ et al. $^{4}$ About $5 \%$ of the normal cytology specimens, $32 \%$ of the atypical squamous cells of undetermined significance (including also ASC-US and ASC-H), 37\% of the lowgrade squamous intraepithelial lesion (LSIL), 93\% of the HSIL, and $99 \%$ of the cancer specimens were found to be positive in p16 cytology which was comparable with our present data where out of 33 abnormal cervical cytology, (24/33) $72.7 \%$ were ASCUS, (6/33) $18.08 \%$ were LSIL, (2/33) $6.06 \%$ were HSIL and (1/33) $3.03 \%$ were SCC but all the abnormal cervical cells tested positive for $\mathrm{p} 16$ reactivity.(Table below). These data are summarized different cytology platforms and systems for p16 cytology assessment were used. Sahebali et al. determined p16-positive cell counts in consecutive slides from a routine cytology laboratory. ${ }^{5}$ Bibbo et al analysed a series of HSIL result and correlated it with biopsy. ${ }^{6}$ In most cases of low grade and high-grade dysplasia p16 was positive.

In our study we focused on the feasibility of p-16 INK4a immunostaining in consecutive 100 cervico-vaginal samples processed by conventional technique in parallel with clinical evaluation of uterine cervix. There are few studies that have compared p16-INK4a immunocytochemistry analysis with conventional Pap smear and visual inspection of uterine cervix. During the last decade technological advances in sample collection and processing have been introduced and implemented in cancer screening programs. But we cannot attempt to replicate the strategies of the developed countries. The burden of cervical malignancy in late stage in most developed countries is about 10 to 12 percent, where as in India it is 70 percent. Our highest priority is therefore to identify disease earlier as stage $1 \mathrm{~B}$ where the cure rate can be significantly high. Pap smear is considered to be the mainstay of cervical cancer screening programs worldwide, but the interpretation of cytological tests still has limitations with great inter-observer and intraobserver variability ranging from $43 \%$ to $68 \%$.

Stoler et al demonstrated the subjective differences in morphology of cervical cytology. It is common specifically with ASCUS, LSIL categories. ${ }^{12}$ In our study we also encountered different morphology of cervical cytology by The Bethesda system 2001 and we found that 33 out 100 were abnormal with conventional smear, 24 were ASCUS (72.7\%), 6 were LSIL (18.1\%), 2 were HSIL $(6.06 \%)$ and 1 was SCC (3.03\%) with 67 were Negative for intraepithelial malignancy (Table 3 and piechart).

Deshpande and Nene BM et al in a rural area in Maharashtra looked at the profile of cervical cytology in women attending their health center and total of 186 women were enrolled. ${ }^{13}$ The mean age of the women in the study was 35.3 years which was comparable to our study with mean age of 41.9 (Table 1 ).

Awasthy et al did a study in Kerela to access the knowledge and practice of cervical cancer in 809 women. ${ }^{16}$ The mean age of the women who underwent 
screening was (34.5 years+/- 9.23) which was comparable with our study where mean age was 41.9 years with SD 10.98. Majority of the women in his study were home-makers $(80.4 \%)$ and $59.6 \%$ were from low socio-economic class (59.6\%). In our study also the abnormal cervical cytology and HPV reactivity was seen in women with low income per family per month (Table $1,4)$.

Table 6: Comparison of various studies.

\begin{tabular}{|c|c|c|c|c|c|c|}
\hline Author & Platform & NILM & ASCUS & LSIL & HSIL & SCC \\
\hline Bibbo $^{6}$ & LBC & & - & $(14 / 19) 74 \%$ & $(25 / 26) 97 \%$ & - \\
\hline Saqui $^{7}$ & LBC & $(5 / 28)(18 \%)$ & - & $(20 / 24) 74 \%$ & $(9 / 10) 90 \%$ & $(1 / 1) 100 \%$ \\
\hline Pientonng $^{14}$ & Smear in PBS & - & $(17 / 30) 57 \%$ & $(10 / 30) 33 \%$ & $(28 / 30) 98 \%$ & $(29 / 30) 100 \%$ \\
\hline Yoshida $^{8}$ & Pap slides & - & $(5 / 38) 13 \%$ & $(7 / 12) 58 \%$ & $(33 / 33) 100 \%$ & $(12 / 12) 100 \%$ \\
\hline Pientong $^{9}$ & Smear in PBS & $0 / 30(0 \%)$ & $(21 / 40) 53 \%$ & $(19 / 35) 54 \%$ & $(29 / 30) 97 \%$ & $(30 / 30) 100 \%$ \\
\hline Bose et al ${ }^{10}$ & Conventional smear & $(3 / 23) 13 \%$ & $(10 / 34) 29 \%$ & $(7 / 34) 21 \%$ & $(13 / 16) 81 \%$ & - \\
\hline
\end{tabular}

Table 7: Comparison of various studies.

\begin{tabular}{|c|c|c|c|c|c|c|}
\hline Meyer et al ${ }^{11}$ & LBC & $9 / 235(5 \%)$ & $(9 / 49) 32 \%$ & $(24 / 57) 42 \%$ & $(43 / 53) 81 \%$ & - \\
\hline Wentzensen $^{4}$ & LBC & - & $(37 / 137) 27 \%$ & $(21 / 88) 24 \%$ & - & - \\
\hline Ekalaksananan & $\begin{array}{l}\text { Conventional } \\
\text { smear }\end{array}$ & $(11 / 148) 7 \%$ & $(12 / 19) 63 \%$ & $(3 / 5) 60 \%$ & $(12 / 12) 100 \%$ & $(2 / 2) 100 \%$ \\
\hline Present study & $\begin{array}{l}\text { Conventional } \\
\text { smear }\end{array}$ & $67 / 100(67 \%)$ & $24 / 100(24 \%)$ & $6 / 100(6 \%)$ & $2 / 100(2 \%)$ & $1 / 100(1 \%)$ \\
\hline
\end{tabular}

Abnormal cervical cytology and HPV reactivity was seen in farm labourers. Twenty-four women out of 50 were farm labourers were positive for immunostaining .Very few women were professional and none of them were reactive to immunostaining of HPV (Table 6). ${ }^{7}$ The findings are in accordance that HPV is seen in low socio economic class (Table 4).

In a study done by Sauvaget $\mathrm{C}$ et al in western India they concluded that the prevalence of HPV infection was more in women from low socioeconomic class, low education level and manual workers. ${ }^{15}$ In our study (Table 1) and the mean income was seven thousand three hundred forty (7340 rupees) with SD (4525.91). The mean income of women who had abnormal cervical cytology and tested positive for immunostaining was rupees five thousand nine hundred forty four per family (5944.44) with SD (12.14). It was seen that the HPV infection was present in women of low socio economy (Table 4).

The strength of our study was that we gave the benefit of index test and reference test to all 100 women. There by doing a blind comparison between the methods to screen cervix. For a country like India with burden of cervical cancer, huge exploratory studies are needed which does not have cost as a barrier.
Funding: No funding sources Conflict of interest: None declared

Ethical approval: The study was approved by the Institutional Ethics Committee

\section{REFERENCES}

1. WHO I. WHO/ICO Information Centre on HPV and Cervical Cancer (HPV Information Centre). Human Papillomavirus and Related Cancers in Kenya Summary Report. 2010;2010.

2. Sartwell PE. On the methodology of investigations of etiologic factors in chronic diseases"-Further comments. Journal of Chronic Diseases. 1960;11(1):61-3.

3. Hilfrich R, Hariri J. Prognostic relevance of HPV L1 capsid protein detection within mild to moderate dysplastic lesions of the cervix uteri in combination with a second biomarker p16. Anal Quant Cytol Histol. 2008;30(2):78-82.

4. Cuschieri K, Wentzensen N. Human papillomavirus mRNA and p16 detection as biomarkers for the improved diagnosis of cervical neoplasia. Cancer Epidemiology Biomarkers and Prevention. 2008;17(10):2536-45.

5. Sahebali S, Depuydt CE, Boulet GA, Arbyn M, Moeneclaey LM, Vereecken AJ, et al. Immunocytochemistry in liquid-based cervical cytology: analysis of clinical use following a cross- 
sectional study. International Journal of cancer. 2006;118(5):1254-60.

6. Bibbo M, Klump WJ, DeCecco J, Kovatich AJ. Procedure for immunocytochemical detection of P16INK4A antigen in thin-layer, liquid-based specimens. Acta Cytologica. 2002;46(1):25-9.

7. Saqi A, Pasha TL, McGrath CM, Yu GH, Zhang P, Gupta P. Overexpression of p16INK4A in liquidbased specimens (SurePath ${ }^{\mathrm{TM}}$ ) as marker of cervical dysplasia and neoplasia. Diagnostic Cytopathology. 2002;27(6):365-70.

8. Yoshida T, Fukuda T, Sano T, Kanuma T, Owada N, Nakajima T. Usefulness of liquid-based cytology specimens for the immunocytochemical study of p16 expression and human papillomavirus testing. Cancer Cytopathology. 2004;102(2):100-8.

9. Pientong C, Ekalaksananan T, Kongyingyoes B, Kritpetcharat O, Swadpanich U, Pengsa P, et al. Immunocytochemical staining of p16INK4a protein from conventional Pap test and its association with human papillomavirus infection. Diagnostic Cytopathology. 2004;31(4):235-42.

10. Bose S, Evans H, Lantzy L, Scharre K, Youssef E. p16INK4A is a surrogate biomarker for a subset of human papilloma virus-associated dysplasias of the uterine cervix as determined on the Pap smear. Diagnostic Cytopathology. 2005;32(1):21-4.

11. Meyer JL, Hanlon DW, Andersen BT, Rasmussen OF, Bisgaard K. Evaluation of p16INK4a expression in ThinPrep cervical specimens with the CINtec
p16INK4a assay. Cancer Cytopathology. 2007;111(2):83-92.

12. Stoler MH, Schiffman M. Interobserver reproducibility of cervical cytologic and histologic interpretations: realistic estimates from the ASCUSLSIL Triage Study. Jama. 2001;285(11):1500-5.

13. Nene B, Deshpande S, Jayant K, Budukh AM, Dale P, Deshpande D, et al. Early detection of cervical cancer by visual inspection: A population-based study in rural India. International Journal of Cancer. 1996;68(6):770-3.

14. Chhabra S, Bhavani M, Mahajan N, Bawaskar R. Cervical cancer in Indian rural women: trends over two decades. Journal of Obstetrics and Gynaecology. 2010;30(7):725-8.

15. Pientong C, Ekalaksananan T, Swadpanich U, Kongyingyoes B, Kritpetcharat $\mathrm{O}$, Yuenyao $\mathrm{P}$, et al. Immunocytochemical detection of p16INK4a protein in scraped cervical cells. Acta Cytologica. 2003;47(4):616-23.

16. Sauvaget C, Nene BM, Jayant K, Kelkar R, Malvi SG, Shastri SS, et al. Prevalence and determinants of high-risk human papillomavirus infection in middleaged Indian women. Sexually Transmitted Diseases. 2011;38(10):902-6.

17. Aswathy S, Quereshi MA, Kurian B, Leelamoni K. Cervical cancer screening: Current knowledge and practice among women in a rural population of Kerala, India. The Indian Journal of Medical Research. 2012;136(2):205.

Cite this article as: Khemka A, Jajoo S. The correlation of visual inspection, Pap-smear and immunocytochemistry of human papilloma virus in detection of cervical cytology. Int J Reprod Contracept Obstet Gynecol 2017;6:176-81. 